En ny arbeidskontrakt som yngre leger i England mener vil svekke pasientsikkerheten, har ført til streik. Også i Norge ser vi en utvikling mot tøffere arbeidsvilkår

\title{
Uro i England
}

Den London-baserte legen Joanne Evans la ut et bilde på Facebookgruppen Junior Doctors Contract Forum en lørdag morgen. Bildet var tatt kl 0715 og viste en folketom t-banestasjon i London sentrum. Under sto det: \#I'matworkjeremyhuntwhereareyou (I'm at work Jeremy Hunt, where are you?). Hun siktet til Englands helseminister, Jeremy Hunt, som vil tvinge igjennom en ny tariffavtale for yngre leger. Forslaget har fått legene ut i streik flere ganger denne våren. Legene protesterer mot endringer som vil føre til lengre arbeidsdager, noe de mener vil føre til utslitte leger og dermed uforsvarlig behandling av pasientene.

Ordinær arbeidstid for engelske leger er i dag kl 07-19. Den nye kontrakten foreslår utvidelse til kl 07-22 på hverdager og kl 07-17 på lørdager (1). Godtgjørelsen er en 13,5\% økning i grunnlønnen for alle yngre leger, et lite beløp sett i forhold til den økte arbeidsbelastningen og fraværet av vakttillegg.

Engelske leger er blant de mest hardtarbeidende av våre utenlandske kolleger (2). De fleste jobber i det offentlige helsevesenet, National Health Service, som flere ganger er kåret til Europas beste offentlige helsevesen (3). National Health Service ligner det norske helsevesenet: Begge tilbyr et gratis, helhetlig tilbud til alle sine innbyggere, med avansert behandling og 24 timers øyeblikkelig hjelp over hele landet. Likevel har National Health Service vært en het potet i engelsk politikk siden Thatcher-perioden i 1980-årene, og det snakkes til stadighet om «A truly seven-day NHS». Ideen er at sykehusene skal driftes likt alle dager i uken, også i helgene. Dårlig helgebemanning skal være en av årsakene til flere dødsfall på lørdager og søndager, og de yngre legene må bidra i større grad enn tidligere, mener Jeremy Hunt (4).

I Storbritannia kan myndighetene innføre en ny arbeidskontrakt uavhengig av hva den engelske legeforeningen sier. Dette vil de gjøre fra 1.august på tross av store protester fra de yngre legene. Både overlegene og pasientorganisasjonene støtter protestene, og meningsmålinger viser at $60-70 \%$ av befolkningen også gir dem sin støtte (5). Likevel trekker konflikten i langdrag. De yngre legene har allerede streiket tre fulle dager, og flere aksjoner er ventet. Grunnen er ikke bare den urimelige avtalen, men også at stor arbeidsbelastning på sikt vil gå utover pasientene. Det engelske folket opplever allerede at kvaliteten på helsetilbudet er i ferd med å falle. Hvorfor tøye strikken som allerede er strukket langt? British Medical Association sammenfatter dette godt i slagordet: «Tired doctors are dangerous doctors».

Vi har heldigvis solide rammer omkring arbeidstid i Norge, med arbeidsmiljøloven som utgangspunkt. Samtidig jobber norske leger rundt tre timer uregistrert overtid per uke, og nesten $60 \%$ av sykehuslegene opplever arbeidet som belastende eller svært belastende (6). Tiltak som gir mulighet til ytterligere utnyttelse av legearbeids- kraften kan derfor være gal vei å gå. Arbeidsgiverorganisasjonen Spekter skriver i Dagens Næringsliv: «I årene fremover vil vi måtte dreie lokalt utviklingsarbeid mer i retning verdiskapning og produktivitet, og vektlegge reguleringer og rettighetsorientering mindre» (7). Ja, vi trenger verdiskapning og økt produktivitet, men det bør komme gjennom god regulering og ved å sikre rettighetene til dem som skal utføre det. Å svekke de eksisterende arbeidsvilkårene bør ikke bli et forhandlingskort.

Hvilken lærdom kan vi i Norge trekke av kampen som yngre leger kjemper i Storbritannia? I Norge er frontene mindre tilspisset, men vi må jobbe for at dette ikke skal bli vår hverdag. Stadig utvidet arbeidstid uten mer ressurser vil på sikt true pasientsikkerheten og kvaliteten. Alle som interesserer seg for arbeidsvilkår og fremtiden for yngre leger bør se til England og utviklingen der. Vi må støtte våre engelske kolleger når arbeidsrettigheter nedprioriteres og når frontene blir hardere. Dette kan en gang bli realiteten i Norge.

\section{Clara S. Bratholm}

clara.bratholm@gmail.com

Clara S. Bratholm (f. 1985) er lege i spesialisering i pediatri på Drammen sykehus. Hun sitter i styret i Yngre legers forening og er visepresident i European Junior Doctors, som representerer mer enn 300000 yngre leger i Europa.

Forfatter har fylt ut ICMJE-skjemaet og oppgir ingen interessekonflikter.

\section{Litteratur}

1. The BMA blog. Ten reasons why the juniors contract talks stalled. www.bma.org.uk/news-views-analysis/the-bma-blog/2014/october/ ten-reasons-why-the-juniors-contract-talks-stalled (27.4.2016).

2. Smith R. Junior doctors are still working 100 hour weeks despite European laws: BMA. The Telegraph 9.4.2014. www.telegraph.co.uk/news/health/news/ 10818708/Junior-doctors-are-still-working-100-hour-weeks-despite-Europeanlaws-BMA.html (27.4.2016).

3. Campbell D, Watt N. NHS comes top in healthcare survey. The Guardian 17.6.2014. www.theguardian.com/society/2014/jun/17/nhs-health (27.4.2016).

4. Sculthorpe T. David Cameron repeats controversial claim stroke victims are 20 per cent more likely to die at the weekend despite top doctors dismissing it as out of date and wrong. The Daily Mail 18.1.2016. www.dailymail.co.uk/news/ article-3404726/David-Cameron-repeats-controversial-claim-stroke-victims20-cent-likely-die-weekend-despite-doctors-dismissing-date-wrong.html (27.4.2016).

5. Majority' support doctors' strike if emergency care given. BBC news 11.1. 2016 www.bbc.com/news/uk-35288042 (27.4.2016).

6. Tveito K. For høy arbeidsbelastning i sykehus. Tidsskr Nor Legeforen 2014; 134: 1289. doi: 10.4045/tidsskr.14.0693

7. Bratten AK. Jeg velger meg april. http://spekter.no/Jeg-velger-meg-april/ (27.4.2016). 